$$
\begin{aligned}
& \text { ポチョムキン・デモクラシー } \\
& \text { プーチンの限界か - } \\
& \text { 永 綱 憲 悟 } \\
& \text { (亜細亜大学国際関係学部) }
\end{aligned}
$$

\title{
Potemkin Democracy: Has Putin Reached his Limit?
}

\author{
Nagatsuna, Kengo \\ Faculty of International Relations, Asia University
}

\begin{abstract}
This paper argues that Russian democracy has become a charade, like Potemkin villages, caused by Putin's personality and his method of leadership.

We can discern four types of viewpoints about the Russian political system under Putin. The first is the "affirmation/optimism" type, as represented by Anatol Lieven's view. He asserts that Putin is a "convinced reformer, dedicated to modernizing Russia". Scleifer and Treisman make a similar argument, advocating that Russia has become a typical middle-income capitalist democracy and noting that the common flaws of such a democracy are not incompatible with future economic and political progress. Russian analyst Vyacheslav Kostikov takes the same view and points out that Putin promotes "a pragmatic democracy", which differs from the western style of democracy.

The second is the "affirmation/pessimism" type, as represented by Russian political scientist Vyacheslav Nikonov. He has a pessimistic outlook for the future, while, to some extent, supporting the current Putin system. The third is the "negation/pessimism" type. American scholar Richard Pipes has a very negative opinion about the present, as well as the future, of the Russian political situation. He asserts that "Russia's democratic institutions have been muzzled" and "its cooperation with the international community far from assured.” Russian sociologist Olga Kyshtanovskaya, known for her elite studies, takes a similar pessimistic position.

The fourth type, to which this paper adheres, is "negation/optimism". Most Russian liberal intellectuals maintain this point of view. Vladimir Ryzhkov, a member of the Lower House, believes that the Putin government is going to take "a modernization model of authoritarianism”. However, he adds that this model cannot overcome such problems as poverty and corruption in Russia. Therefore, in his view, opinions demanding big changes will increase around the time of the government elections, from 2007 to 2008. Russian political scientist Lilia Shevtsova takes a similar position and expects a growth of grass-roots democracy in Russia.
\end{abstract}

Keywords: Russia, Democracy, President, Putin, Election 
We can verify concretely the deficiencies in Russian democracy by looking at the process of the national election campaign in 2003 and 2004. The OSCE election monitor group concluded that the election process for Parliament, as well as the President, did not reach the international standards of a democracy.

Russian political journalist Elena Treguvova confirms that Putin's political outlook and behavior are not suited to politicians in a democratic country. She asserts, first, that Putin has no charisma as a public politician. Second, Putin is an expert who "mimics" the manner of the person to whom he is talking. Third, Putin often takes a strong attitude when someone points out problems in his work. Fourth, Putin used to be extremely faithful to an order from a superior official. Fifth, Putin is bluntly strengthening control over the media.

Under such a president, we cannot expect Russian democracy to make progress. Putin's limits are not, however, the Russian nation's limits. It is, therefore, groundless to assume that Russia will never become a democratic country in the future.

はじめに

ロシアの民主主義は, 見せかけの，ポチョムキン的なものとなっており，それはかなりの程 度，プーチン自身の個性あるいは政治手法が生み出したものである，というのが本稿の主張で ある。それは，「新時代のロシア・東欧」という本号の特集タイトルとはやや逆行するような 見方であるが，その背景には，東欧および一部旧ソ連諸国が欧州拡大の波に組み込をれるのと 対照的に，ロシアが半ば過㮃防衛的に権威主義傾向を強めているといら事情がある。

以下，プーチン体制についての四つの見方を紹介したのち，03-04 年の国政選挙を素材に民 主主義からの逸脱現象を確認し，最後にプーチンの「民主主義」観を分析する ${ }^{(1)}$ 。

1 プーチン体制論一四つの見方

\section{（1）肯定・楽観論}

A・リーヴェンによれば，プーチンはロシアの近代化と世界経済への組み入れを求めている

(1) 本稿は, 2004 年 9 月に提出した学会報告用原稿をもととしている。学会では多くの方から貴重なコメ ントを頂戴した。またその後ロシア政治のらえでも，いくつかの重要な事件が生じた。しかしなが ら, 筆者の当初の分析枠組及は基本的には現在でもな和有効と考元ている。したがって本稿では, 若 干の字句修正をのぞいて，報告用原稿をほぼそのまま利用することとした。学会での応答については 後揭注（22）で多少整理を行った。またロシア政治の重要事件としては, 2004 年暮れのウクライナで の親欧米政権の成立と 2005 年初頭の「社会保障特典の現金化」実施に伴う混乱と反発がある。いず れも別個に論ずべき大きな出来事であり本稿ではとりあげないが，これらの出来事を経た時点での各 論者のプーチン体制論の推移については，それぞれの注の中でいくらかフォローした。さらにこれら の出来事を受けて，(むろんユコス事件や知事選挙の廃止なども含めて)，二期目の米国ブッシュ政権 がロシアの民主主義進展に公式に危惧を表明し，ロシアがこれに反発するといら事態が生じている。 しかし，本稿ではこの問題には言及しない。

なお，「ポチョムキン民主主義」といら表現はロシアでの政治論評でも時折使用されているが，こ れを副題とした論文としては, William A. Clark, “Russia at Polls, Potemkin Democracy,” Problems of Post-Communism, March/April 2004, pp. 22-29がある。また，『宮崎日日新聞社説（2003 年 12 月 9 日)』 に,「「ヤブロコ」代表のヤブリンスキー氏はかねて、プーチン体制下の「管理された民主主義」を「ポ チョムキンの村」と表現，警鐘を鳴らしてきた」という指摘のあることに，学会発表後，気づいた。 [http://www.the-miyanichi.co.jp/news/index.php3?PT =4\&DT =20031209] 
「確信をもった改革者」である。近代化しつつある国家を「財閥の無政府状態」および「苦し んでいる大衆の反乱」から守ることが重要であり，そのためにテレビメディアの統制も必要で ある。「ロシア国家の中核権力を保持することは，安定的で成功した資本主義にとっても，一 般のロシア国民の長期的な自由にとっても重要」であり，資本主義的経済成長が次の世代をか けてミドルクラスを生み出しのちに，初めて，ロシアの民主主義が確立されるとリーヴェンは いうのである(2)。

ほぼ同様の議論は, シュライファー\&トレイスマンの「ノーマルな中位所得国」論において も主張されている。彼らは現在のロシアを，90年代のアルゼンチンやメキシコ同様の，「典型 的な中位所得国」と位置づけ，この中位所得国では，「未整備の部分が多く，政府は腐敗し， 裁判は政治化され，言論は完全に自由とはいえない」とする。しかし，ロシアの「2003 年議 会選挙で有権者が以前の選挙よりも圧力をかけられた」という議論は疑わしく，そもそも年平 均 $10 \%$ 以上の所得増を経験しているなかで,「親プーチン政党がもしも人気がなかったら驚き であろら」とする。彼らによれば, 19 世紀の欧米が欠陥を克服して発展したように,「中位所 得国」も将来の政治経済発展の可能性をもっているのである(3)。

同様の議論はむろんロシアの論者の中にもみられる。たとえば『論拠と事実』紙でコスチコ フは，ロシアが「奇妙な民主主義」であり，「頭は西側的，胴体はソビエト的，膝までは（と くに地方では）封建制的，だが首を動かしているのは大統領」という事実を承認する。そのう えでコスチコフは，「ロシア人は民主主義に慣れてきている。もはやロシア人は民主主義から 離れることを望んでいない」とし，プーチンが，西側とは異なる「実際的民主主義」を推進し ていると主張している(4)。

\section{（2）肯定・悲観論}

プーチン体制の現状をある程度擁護しつつ, 将来については悲観的な展望をもつ, というや や風変わりな議論を展開しているのがロシアの政治学者ニコノフである。彼は，ロシアには 「権力分割」も「司法改革」もないが，その一方で中央の命令にすべてが服従するような権威 主義も成立していないとする。ニコノフによれば現在ロシアは「無制限のアナーキー」から 「抑制されたアナーキー」へ向かって拈り，マスメディアについても今な拪側より「わずか ながら自由」であるとする。このように述べながらもニコノフは，ロシアが，その「遺厷子 コード」を克服するのは容易ではなく，「ロシアは改革がたいへん難しい国」であると結論す るのである(5)。

\section{（3）否定 : 悲観論}

現状についても, 近い将来についてもネガティヴな立場をとっているのが米国のロシア研究

(2) Anatol Lieven, “Modernising Putin’s “managed democracy'," Financial Times (UK), July 23, 2004. その後欧 米でのプーチン批判が強をるなかでも，リーヴェンはプーチン評価の姿勢を維持しており，もしプー チンが失脚したら，「よりナショナリスティックで，より反西欧的で，よりポピュリスト的で，より 市場経済改革に不熱心な」指導者がとって代わるだろうと欧米の論者に対して警告している。“The Essential Vladimir Putin'," Foreign Policy, January/February, 2005.

(3) Andrei Shleifer and Daniel Treisman, "A Normal Country," Foreign Affairs, March/April 2004, pp. 20-39?

(4) Argumenty i Fakty, no. 34, August 25, 2004.

(5) Vyacheslav Nikonov, "Putinizm," in V. Nikonov (ed.), Sovremennaya Rossiskaya Politika (Olma-Press, Moskva, 2003), pp. 29-43. 
者 R・パィプスである。パイプスによれば，ソ連崩壊後の期待に反して，プーチン後，民主主 義は抑制され，国際社会との関係も不安定になっている。しかも厄介なのは国民自身がそうし た事態を望んだ面があるといらことである。パィプスは，ロシアでは伝統的に国民の社会的な 結束が弱く，市民権が無視され，私有権の真の観念がなく，国民が「強いッァーリの支配」を 望んできたという持論を披瀝したのち，世論調査データをあげてそれを確認している。たとえ ば国民の $78 \%$ が「民主主義は富者もしくは権力グループに支配された政府の外見にすぎない」 と考えている，あるいは「私有財産を重要な人権の一つ」とみなす者は 4 人のうち 1 人にすぎ ないといった数字をあげる。プーチンの人気は何よりも彼が「ロシアの伝統的な統治モデル」 すなわち「専制的国家」を復活したことから来ている。そのもとでは「市民は政治に対して責 任を負わず，人為的な統一を作り出すために想像上の外敵が引き合いに出される」のである。 パイプスはこのように結論した後, いずれロシアが軍事面でも全面復興にとりかかるであろら とみている(6)。

ロシアではさすがにパイプス臣の全面的な否定論はないが，あえてあげれば エリート研 究で知られる社会学者クリシタノフスカヤがかなり否定的かつ悲観的な立場をとっている。彼 女によれば，いまやシロヴィキ勢力（治安機関，検察，軍）が権力の中枢を支配するように なった（かつての治安機関周辺部分の出身者を加えると権力エリートの 77\%を占める）。この シロヴィキたちの発想では，「秩序」とは上官への無条件の従属にほかならず，議論や意見の 多様性はカオスである。内外に敵があって，外には西側がロシアの崩壊を望んでおり，内には 西側の同盟者, 第五列がいる。諜報員はそらいら世界観を今日まで保持しているとクリシタ， フスカヤは指摘する。次の大統領選挙に打いては, いろいろなシナリオ（大統領第三期目, プーチン首相の議会共和国，継承者，国家連合等々）がある。だが真の意味で「国民が選挙す るといらことだけはありえない」と彼女は見ている(7)。

\section{(4) 否定・楽観論}

プーチン体制の現状を批判的にとらえつつ, その統治に限界があり, 早晚, 民主的諸勢力が 復活する可能性があるとする議論である。ロシアのリべラル派知識人の多くはなおこの钼点を 維持している。たとえば下院議員のウラジーミル・ルイシコフはプーチン政権が「権威主義的 近代化モデル」をとろうとしていると把握したうえで, このモデルでは結局, 負困問題, 腐敗 問題などの克服は達成できないとする。それゆえ 2007 年から 08 年にかけての国政選挙の時期 に大きな転換要求が起きると彼は見ている(8)。

(6) Richard Pipes, "Flight From Freedom: What Russians Think and Want," Foreign Affairs, May/Jun 2004, pp. 9-15.なおロシアの政治評論家 A・ルキンは, パイプスが「現在の反民主的ムード」を過度に一般化 していると批判している。Alexander Lukin, "Pipes Can’t See the Trees for the Forest," Moscow Times [http://www.moscowtimes.ru], July 21, 2004.

(7) Nezavisimaya Gazeta [http://www.ng.ru/], August 31, 2004. その後クリシタノフスカヤは, 抵抗運動拡 大について, やや楽観的な見方をするようになっている。最近の新聞インタビューに拮いて, 彼女 は, 現政権エリートの行政運営能力・知性不足を指摘し, エリートが社会からかけ離れて存在するゆ えに事態が「擬似制御あるいは擬似管理」に行き着くと述べ，大衆的な抵抗運動が桩大する可能性も あるとしている。彼女によれば，たしかに，組織された野党勢力の不在は否定できないが，国民が指 導者を求めているがゆえに, 野党の指導者が「必ず, 急速に現れるであろら」というのである。Ibid., February 18, 2005. 後掲注（9）のシェフッォーワがやや慎重になっているのと対照的である。

(8) Vladimir Ryzhkov, "Ogranicheniya avtoritarnoi modernizatsii khorosho izvestny," Gazeta ru [http://www. gazeta.ru], March 22, 2004. 
政治学者シェフッォーワもほぼ同様に，現状が 1960-70年代にラテンアメリカで見られた 「官僚的権威主義体制」に近似した体制となっているとみる。だがその体制が成功するために は，「結束した軍事エリート」，「有能な官僚」「カリスマ的指導者」などが必要であり，ロシ アにはそうした条件が欠けているとする。しかも，かつての官僚的権威主義体制の課題が農業 社会から工業社会への転換であったのに対して, 現在のロシア近代化の課題はより複雑であ り, 過剰な集権化はかえって近代化の障碍となる。選挙操作には限界があり, 草の根の民主主 義の扗大如何によって，2008 年がターニングポイントとなる可能性もあるとシェフッォーワ も見ている(9)。

こうして見てみると, 肯定的な見解でさえも，かなりの留保付きであり，やはりロシア民主 主義の現状は否定的に捉えざるを得ないように思える。国政選挙をとりあげてやや具体的にこ の点を確認しておこう。

\section{2 二つの国政選挙一民民主主義基準からの逸脱}

OSCE（欧州安保協力機構）のロシア選挙監視団は, 2003 年末の下院（国家会議）選挙と 04 年の大統領選挙について，いずれも民主主義の基準に達しないものと総括した。以下，同監視 団の総括報告書を主たる素材として，プーチン政権下のロシア国政選挙の実態を確認する(10)。 まず下院選挙について，民主主義の見地から問題となりらるのは大きく以下の 3 点である。

\section{（1）統一ロシア党の候補者による地位利用}

同党比例区候補者 (262 名) には, 現職の閣僚 (内相, 緊急事態相, 産業科学技術相), 次 官（内務省, 緊急事態省 2 名, 対外諜報局）および構成主体首長（29名）など高位の役職者 が数多く含まれていた。有力知事の比例区名簿掲載について，ある論者は「クレムリンと統一 ロシア党が事実上知事を人質にとった」と評した(11)。現職知事はクレムリンからの誘いを断

(9) Liliya Shevtsova, "Kak Rossiya ne spravilas' s demokratiei: logika politicheskogo otkata," Pro et Contra [http://www.carnegie.ru/ru/pubs/procontra/], tom. 8, no. 3, pp. 36-55.

シェフッォーワは，2005 年 1 月の論考において，ロシアに「体制危機の兆候」が出現したとし，経 済政策面を含めて, 官僚的権威主義のもたらす危険性を広範に考察している。そこで興味深い点は第 一に，ウクライナやグルジアで生じたような革命的状況はロシアでは期待できず，歴史類推から見て もむしろロシアが逆にいっそう反動的方向に向から可能性が強いとしていることである。第二に，こ れと関連して, 現政権が, 危機状況に直面して, 暴力を行使する危険性も否定できないとみている点 である。このように, 逆説的ではあるが, プーチン政権の問題点が誰の目にも明らかになった時 点で, 彼女の議論は, 当初の楽観よりは, やや慎重なトーンになっていることに留意しておきたい。 なお，第三の注目点として，過去の評価にかかわる点であるが，2000年の終わりから 2001 年にかけ て，プーチンには旧体制を大きく解体できるチャンスがあったと主張しているのも興味深い。 Nezavisimaya Gazeta, January 21, 2005.

(10) 以下は，とくに記した部分を除き，OSCE 選挙監視団報告書に依拠している。OSCE/ODIHR (Office for Democratic Institutions and Human Rights), Election Observation Mission Report. Russian Federation, Elections To The State Duma, 7 December 2003 (Warsaw, 27 January 2004) および Presidential Election, 14 March 2004 (Warsaw, 2 June 2004) [http://www.osce.org/odihr/index.php?page=elections\&div=rep orts\&country=ru].

なお二つの国政選挙について邦語では, 上野俊彦「ロシアの内政動向，2003 年 12 月国家会議選挙 と 2004 年 3 月大統領選挙を中心に」, 『国際問題』, no. 531 (2004 年 6 月), 2-17 頁が簡潔な整理を行っ ている。また拙稿「二つの国政選挙とナショナリズム」,『海外事情』, vol. 52, no. 6 (2004 年 6 月), 16-29頁もほぼ同様の整理を行っている。

(11) Vedomosti [http://www.vedomosti.ru], September 19 および October 10, 2003. 
ることができず，いったん名簿に載ったからには地元で一定の集票を余儀なくされたからであ る。

そもそも役職候補者の多くは，実際に下院での活動を考えては扣らず，当初からそれを公言 する者もあった。実際, 統一ロシア党の比例区当選者 120 名のうち，37名（31\%）が当選後 議員就任を辞退した。この行為は違法ではないものの, 大規模に行われた場合, 「有権者を惑 わす」ものであると OSCE 報告書は指摘している。

また地方レベルの選挙委員会編成において地方行政府の影響が大であり，実質上「統一ロシ ア」党員の偏重がみられた。時には，投票所が一週間前まで統一ロシア党選挙事務所と同じ場 所といらケースもあった（ヴォロネジ）。その他の行政機関の事務所を統一ロシア選挙事務所 としているケースも多くみられた。ニジェカムスク（タタールスタン）では, 統一ロシア党選 挙事務所はヴォルガ管区大統領全権地方事務所のなかにあり, 地方政府から設備とサーヴィス の提供を受けていた。

\section{(2) マスメディアにおける統一ロシア党偏重}

選挙法により，各政党に無料の政見放送時間が与兄られて扣り，この点では扱いはかなり公 平であった。問題なのは，一般のニュースでの各政党の扱いであった。OSCE 監視団が行った 調査では, ニュース報道において, 第一チャンネルでは, 統一ロシア党が全ニュースの $19 \%$ （肯定ないし中立的報道）を占めていたのに対して，共産党 13\%（内容はほぼ否定的）であり， ロシアテレビでは統一ロシア党 16\% (肯定的), に対して, 共産党はごくわずか（否定的）で あった。個別事例としては, 統一ロシア党指導者グリズロフがロシアテレビのニュース番組に 出演しギターを演奏したケース，ペルミ州選挙委員会局が地方局による共産党議長ジュガーノ フの同地での選挙演説報道を禁じたケース，などがあった ${ }^{(12)}$ 。

\section{（3）対立候補の登録拒否}

立候補登録拒否について OSCE 報告書は一般にその判断基準が不明瞭であることを指摘し ている。たとえば元検事総長スクラートフは今回の下院選挙でブリヤート共和国第 9 選挙区か ら立候補を試み，同選挙区選挙委員会により登録を拒否された。スクラートフの訴えを受けた 中央選挙委員会は，当初訴えを認め，登録のやり直しを命じた。ところが地元の選挙委員会は 再度スクラートフの登録を拒否した。再度の訴えを受けた中央選挙委員会は, スクラートフが 虚偽の職歴報告一一提出文書ではモスクワ国家社会大学の講座「主任代行」と記していたが, 実際には当該講座の「教授」であった—ことなどを理由として登録拒否の決定を追認し た ${ }^{(13)}$ 。スクラートフ以外にも, 元副大統領ルッコイ, クラスノヤルスク元工場長ブィコフ, ニジニノグドロド元市長クリメンッェフなどが立候補を認められなかった。いずれも無所属も しくは共産党の候補者であり, 統一ロシア党候補者が登録を拒否された例は報じられていな い。

ついで大統領選挙については, そもともプーチンの再選が確実視されており, 主要政党指導 者はプーチンとの正面対決を回避した。このため, プーチン陣営は選挙への関心が薄れて投票

(12) $R F E / R L$, Newsline [http://www.rferl.org/newsline/1-rus.asp], October 9 㧊よび October 23, 2003.

(13) 中央選挙委員会の決定については, 同委員会ウェブページで確認できる。http://gd2003.cikrf.ru/ 470_post 打よび http://gd2003.cikrf.ru/537_post_1. 
率が低下することを最も恐れた。この選挙プロセスで観察された逸脱現象として以下の 4 項目 をあげることができる。

\section{（1）投票率引き上げのための不当な動員}

一般にどの地域でも投票呼びかけポスターがあふれており，投票所ではミ二演奏会や食料品 の廉価販売も各地で行われていた ${ }^{(14)}$ 。こした一般動員体制を越えて, 明らかな違法行為も 各地で散見された。入院予定者に事前投票を義務づけた例（ハバロフスク，ヴォロネジ）や学 生証（試験登録のさいに使用）に投票済みスタンプを押した例（ハバロフスク）などが報道さ れた。サラトフとバシコルトスタンでは有権者が，雇い主から失業の脅しをかけられて，不在 者投票を強いられた例があった。

\section{（2）行政資源の利用と対立候補への圧力}

モスクワでプーチン陣営がアパート管理人に署名集めを依頼した例，またイルクーツクで経 営者代表による職場でのプーチン署名集めが行われた例がある。さらにモスクワ南部では選挙 委員会がプーチン支持と見間違えるような内容［「希望は途上（プーチ）にある」] の投票呼び かけポスターを揭示していた。ニジニノヴゴロドでは，開票をほぼ半分すませたところで投票 所選挙委員長と書記が投票リストをもって突然退出し，45 分後に戻ってきた。そのさいプー チン票 50 票が追加された。対立候補への圧力に関して述べると, とくに露骨な圧力を受けた のは，下院選挙で躍進した〈祖国ブロック〉所属のグラジェフ候補であった。テレビでは，彼 の陣営が署名を現金で買い上げていることを示唆する報道がなされた。さらに地方での選挙集 会や記者会見においては，「爆弾騒ぎ」その他の理由で建物の使用を再三拒否された ${ }^{(15)}$ 。

\section{（3）マスメディアにおけるプーチン偏重}

下院選挙同様，無料の政見放送については，ほぼ公平に各候補者に提供された。しかしプー チンは, 統一ロシア党同様, 候補者間のテレビ討論に参加しなかった。このため対立候補は現 職大統領に対してその業績にかんして質疑を行らことができなかった。その一方で一般の ニュースではプーチンの言動がつねにとりあげられていた。OSCEの調査では, 選挙前の 4 週 間において，第 1 チャンネルはニュースでプーチンを 4 時間以上とりあげた。第二位の共産党 候補ハリトノフについては 21 分にすぎなかった。とりわけ問題視されたのは 2 月 12 日プーチ ンが選挙代理人集会で行った質疑応答の模様を第一チャンネルが 57 分， ロシアテレビが 62 分 にわたって放送したことである。これについて中央選挙委員会は当該テレビ局に対して, 全候 補者を対等に扱らよう伝えたのみで，実質的対応はまったくとられなかった ${ }^{(16)}$ 。

\section{（4）特定地域における異常に高い支持率}

北カフカースの民族共和国を中心に投票率とプーチンの得票率が異常に高い地域がみられ た。これらの地域で国民の政治参加意識が日常的にとく強いわけでもなく，高いプーチン支持

(14) Kommersant Vlast', no. 15 2004, pp. 13-16.

(15) グラジェフの選挙運動への圧力については前掲拙稿拈よび Laura Belin, “Glazev gambles and loses,” RFE/RL, The Russian Federation Votes: 2003-04, 17 March 2004 [http://www.rferl.org/specials/russianelection/].

(16) この件についての中央選挙委員会決定は, http://www.cikrf.ru/_1/doc_5_1.htm. 
を生むような要因があるわけでもない。むしろ，すでに見てきたように運動妨害や行政資源利 用が頻繁にみられた地域である。それゆえこれら地域では何らかの圧力あるいは不当な動員が 行われたといら推測が可能である(17)。

かりに以上のような逸脱行為がなくても, 統一ロシア党は第一党となり, プーチンは圧勝で あったろう，という推測は可能である。だがそこから逆に選挙が民主的であったと主張するこ とはできない。手続き的な公平・公正を欠いた選挙を民主的とはいえないからである。むしろ プーチン政権のもとで, 選挙が，民主主義の形を借りた権力維持装置の一部と化していること に留意すべきであろう(18)。

\section{3 プーチンの「民主主義」観一一擬態」としての民主主義}

それではプーチン自身は民主主義をどのようなものと見ているのだろらか。彼は 2004 年 5 月, 再選後の最初の年次教書において, 次のように述べて, 自らの「民主主義」信奉を強調し た。「成熟した市民社会なしに人々の日々の問題の効果的解決は不可能である」「自由な人々か らなる自由な社会をロシアに創ること—これが我々の最も重要な, そして最も困難な課題で ある。この民主主義賛美の特徵は，それが一般的抽象的であり，具体イメージをほとんど 伴っていないことである。

対照的に， ロシアの民主主義の欠陥について述べる時には，プーチン発言は以下のようにか なり具体的である。「文明的政治的競争が役得収益を得るための利己的争いに取って代わられ ること, 政治団体の活動の財政的側面が以前同様, 社会から隠されていること, 選挙技術と口 ビイスト・サーヴィス市場が闇の部門で行われていること，こうしたことは許し難いことであ る」「一部の NGO 組織は影響力ある外国財団から資金を得ることを第一の課題としている。 また一部組織は疑わしい集団利益や商業利益に奉仕している」(19)。

このょうに民主主義の不十分さは，何よりも，商業利益との関連で，また外国財団との関連 で理解されている。つまり, プーチンの民主主義イメージには, 自らの権力の行動一テロ事 件への対応ぶりから選挙での行政資源利用にいたるまで—が，独立したメディアや知識人に よって, 時には外国諸組織によっても吟味され，批判されるといら側面はほとんど含まれてい ないのである。ロシアのポチョムキン的民主主義の現状は他ならぬ大統領自身のこうした民主 主義理解にふさわしいものである。

プーチンのこらした政治観については，昨年公刊されたクレムリン番女性記者トレグーヴォ ワの回想録でも明らかにされている(20)。それによれば，第一にプーチンは，本来政治に関心 が薄く，また公的政治家としてのカリスマ性をもっていない人物である。97 年 5 月の大統領

(17) 高投票・高得票地域については前掲上野，16頁拈よび拙稿，25頁。なお，筆者が関わったロシア民 間 NGO の大統領選挙監視団のらち，タタールスタンに派遣されたグループは，同地の治安関係者に より, 不当な压力を受けた。また同時に行われていた地方議会選挙の開票のさいに, 立会人から異議 を申し立てられた投票所選挙委員長が投票用紙をすべて持ち去り，約一時間後に現れるといら事態も 観察されている。

(18) ソ連末期から現在までの選挙の意味合いの変化については, Michael McFaul, Nikolai Petrov, “What the Elections Tell Us," Journal of Democracy, vol. 15, no. 3, (July 2004), pp. 20-31. とくに 27-29 頁。

(19) Poslanie Federal'nomu Sobraniyu Rossiskoi Federatsii, 26 May 2004. ロシア大統領ウェブサイト [http:// www.kremlin.ru/mainpage.shtml]より。

(20) Elena Treguvowa, Baiki Kremlevskogo Diggera (M., Ad Marginet, 2003). トレグーヴォワは『コメルサ ノ 


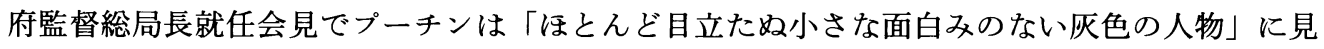
えた（111-112 頁)。第二にプーチンは，話し相手の態度を「擬態」する名人である。トレグー ヴォワによれば，プーチンと差し向かいで話していると，まるで彼が「自分と同じ関心をもっ た仲間の一人」のように思えてくる（実際にはまったく自分と対照的な人間であるにもかかわ らず)。その秘密は，プーチンが「天才的な〈擬態者〉であり，鏡のように相手を模写できる」 といらことにあった。この能力は外交面でも発揮され，時に公式写真に「二人のブッシュ，あ るいは二人のシュレーダー」がいるかのような事態が生じている時がある (166 頁)。

第三にプーチンは痛いところつかれると, 逆に相手を威跡し, 強い態度に出ることが多い。 腐敗した知事を逮捕できないクレムリンの無力さを指摘されると, プーチンはFSB 機関への 期待を表明したあと,「必要なら逮捕する」と語った。その際彼は「強い調子の言葉を，こと さら下唇を擦らせて発音した。「自分と機関を邪魔する者は誰であれ容易に粉砕できるかのよ らに思わせようとしていた。」(144 頁)。あるいは特定の財閥のみが捜査対象となっているの ではないかといら指摘に対して，プーチンは，歯医者についてのアネクドートを持ち出し，健 康な歯を拔かれて怒る患者に対する医者の言葉をあげた。すなわち，「心配はいらない。我々 は遅かれ早かれ虫歯に行き着くのだから。」(158 頁)。

第四にプーチンは上司への命令に対してきわめて忠実である。腐敗した知事の逮捕について も，それを望んでいなかった当時の大統領府長官ユマシェフの命令に「無条件に従った」(148 頁)。あるいはエリッィンの三選をめぐる憲法裁判所の判断について, プーチンは「もしも出 馬が必要であれば，そらいら決定がなされるだろう」と語った（85 頁）。普遍的な法規よりも 権力者の意向を優先させる発想である。

第五にプーチンは露骨にメディア統制を強化した。「プーチンが大統領代行に就任した時か らクレムリンのプレス担当のやり方が即座に根本的に変化した。「プーチンについて批判的 な，あるいは十分に忠実でない記事を書いた記者が取材許可を取り消されるのが日常のことと なった。」(245 頁)。たとえば，2002 年末大統領のビシケク訪問からの帰途のさいに，記者及 び随行員の搭乗機が不良燃料注入により途上で強制着陸となった。そのさい大統領プレス担当 は「むろん皆さんにはこの事故について書く権利がある。だが我々には次の大統領旅程のさい に皆さんの同行取材を認めない権利がある」と語った（364頁）。

このように公的な政治家としてのカリスマに欠け, 威嚇と命令と統制を主たる統治手法とす る人物の民主主義礼賛はいわば一種の「擬態」でしかない。こうした大統領のもとで, 民主主 義が進展することはまずありえないだろう。実際, 2004 年 9 月 13 日, プーチンは首長全員を 集めた拡大閣僚会議で, テロへの対応策の一環として, 下院一人区廃止と首長の事実上の任命 制への転換を実施するよう求めた。これは民主主義慣行からのさらなる後退であるとして，内 外からの批判を招くこととなった ${ }^{(21)}$ 。本稿の文脈でいえば，弱点を突かれたプーチンがもは や面倒な擬態をかなぐり捨てつつあると見るべきであろう。

フント』紙ほか記者として 1997 年から 2003 年はじめまで大統領府内に出入し，大統領の内外旅程にも 幾度となく同行した。回想録は政治事件の記録としてではなく，あくまで「個人史」として執筆され ており，そのまま同時代政治史として取り扱えるわけではない。だがプーチン，ヴォローシン，ユマ シェフ, スルコフ, ネムッォフ, チュバイスほか重要政治家たちの人間的（あるいは非人間的）言動 と, クレムリンによるメディア規制の実態がリアルに描写されており，貴重な情報を提供してくれて いる。以下本稿では, プーチン関連記述を拔粋し，やや強引に整理した。な拉（）で参照頁を示す。

(21) 別個に論ずべき大事件であるが，さしあたり，連邦制を定めた憲法との関連での，下院議員ウラ 厂 
かくして二期目のプーチンのもとで，これまで以上に政治的統制が強化されることはほほ間 違いない。そのもとでロシアが経済的にさらに発展するのか（そして民主主義の基盤が築かれ るのか)，あるいは逆に経済発展の行き詰まりで国民が爆発するのか，それは定かではない。 しかし，20世紀後半の世界史をみれば，民主主義を達成できないと思われていた国が安定的 な民主主義国となった例は数多い。21 世紀にロシアが民主主義を達成できないとする根拠は なにもない。プーチンの限界はロシア国民全体の限界ではないからである(22)。

】ジーミル・ルシコフの指摘をあげておく。Kommersant [http://www.kommersant.ru/], September 14, 2004. その後 2004 年 12 月に事実上の知事任命制を内容とする連邦法修正が行われ, 大統領に地方議 会の解散権が与えられた（修正法の全文は Rossiskaya Gazeta [http://www.rg.ru/], December 15, 2005 に 掲載された)。さらに 2005 年 1 月 31 日, 最初の事例として, 沿海地方知事ダリキンが大統領により 推庶され，2月 4 日，同地方議会に上り承認された。なお，2005 年 3 月 9 日，コリャーク自治管区知 事ロギノフが「大統領の信頼を失ったこと, また自らの義務遂行の失敗」により（具体的には地域の 暖房供給不備により）解任された。ロギノフは新制度導入以前に住民に直接選挙でされた知事であっ たが，そうした人物についても大統領が容易に解任できる仕組みであることが明らかとなった。以上 について, Interfaks [http://www.interfax.ru/], January31, February 4 and March 9, 2005.

(22) 学会報告後の質疑では多くの有益な指摘を受けた。そのなかから三点のみについて少し整理しておき たい。第一は，プーチン政権下の選挙の公正性等を論じるには，より広範にエリッィン時代，あるい はそれ以前からの選挙のあり方の推移，比較考察が必要ではないかといら指摘（上野俊彦氏）につい てである。ロシア政治の特質について，より深い議論をするらえで，そらした作業が必要であるとい らことに異論はない。前揭, 注（18）で言及したマックフォールはある程度そらいら試みを行ってい る。ただ, そのことを一応切り離して, 国際的基準からみてプーチン政権下の選挙が公正なものか否 かを問らことも可能かつ必要であると筆者は考えている。

第二は，プーチン下のロシアが民主主義とは言旮ないといらことはもはや自明のものとして，むし ろその非民主主義の特質を他の国との比較などを通して明らかにすべきではないかといら指摘（木村 汎氏）についてである。これについてもまったくご指摘の通りである。この指摘は, 私見では, 非民 主的な政治と経済的発展の関係をどう捉えるかという問題とも結びついている。重要な問題である が，現在の筆者にはそれを検討する準備が出来ていないといらのが正直な回答である。

第三に，結論部分で，一般論的に民主主義の可能性を持ち出すのはあまりに唐突ではないかという 指摘（横手慎二氏）である。この指摘についても基本的には甘んじて受け入れるしかないが，筆者の 意図は，パイプス的悲観論（ロシアでは民主主義は創出できない）とも，リーヴェン的楽観論（指導 者プーチンに期待できる）とも異なる第三の観点（現状は問題多いが将来は分からない/プーチンに は問題多いがロシア国民には期待できる）があることを打ち出すことにあった。今後，第三の観点に ついて, より実質的根拠を詰める必要があるが, 「社会保障特典の現金化」をめぐっての 2005 年初頭 の国民行動は，筆者の観点（ないし期待）をいくらかは裏付けているょらに思える。 